texture, and the clinopyroxene and spinel often show a symplectic relationship. In addition, the phlogopite shows wavy extinction and some kink banding. Finally, in PTH 108, 202 and 516, garnets are absent and all that remains in their place are pools of coarse-grained phlogopite, chrome diopside, and chrome-rich spinels (Fig. 1E). Phlogopite is generally the most abundant phase, and the chrome diopsides are characterized by clear cores and cloudy rims.

Representative analyses of the collar and pool minerals are summarized in Table 1.

Single pyroxene thermobarometry (Mercler 1980) on the collar and pool chrome diopsides might be expected to show equilibrium conditions different from those obtained for more normal nodules from Pipe 200 (Carswell et al. 1979; Mitchell et al. 1980), but the excess of $\mathrm{Na}$ over Al (cations) in these pyroxenes proved to be unsultable for that particular calculation. The phlogopites of the collars and pools are primary according to the classification of Carswell (1975), and this is interpreted to mean that they are of earlier mantle, rather than of later diatreme, origin.

\section{Collar and Pool Formation}

From the textural relations shown in Fig. 1, it is clear that the collars and pools have formed largely at the expense of garnet. Such fertile clots of minerals could not have survived the partial melting event as demanded by the depletion of the whole-rock composition, therefore collar and pool formation post-dated the partial melting event. The coarse-grained texture of the collars and pools, the deformation of the phlogopites and the primary chemical compositions of the phlogopites all suggest that collar and pool formation predated the kimberlite diatreme event. Thus the time of formation of the collars and pools is bracketed between the depletion and diatreme events.

It is possible that the collars may represent the products of the retrograde reaction, olivine + garnet $\rightarrow$ opx (grain growth outside the collar) + cpx + spinel, with either decreasing pressure in an ascending diapir, or with decreasing temperature after the partial melting event, or both. However, the presence of minor phlogopite in the collars suggests that metasomatic fluids rich in $\mathrm{H}_{2} \mathrm{O}$ and $\mathrm{K}_{2} \mathrm{O}$

were at least involved in inftiating garnet breakdown. The pools, with up to $80 \%$ phlogopite after garnet, are clearly the result of mantle metasomatism, and from the range of textures developed (Fig. 1), this reaction had progressed to different degrees. Although there is no evidence in these samples to help distinguish between the metasomatismbefore-magmatism model of Boettcher et al. (1979), and the metasomatism-after-magmatism model of Wyllie (1980), it is believed that the extent of collar and pool formation in the Pipe 200 nodules is more likely a function of the distance of these rocks from a water-saturated magma (either kimberlite, or fractionating to become kimberlite) prior to their incorporation into that magma and rapid ascent to the surface.

\section{References}

Boettcher, A.L., J.R. O'Neil, K.E. Windom, D.C. Stewart and H.G. Wilshire (1979): In "The Mantle Sample: Inclusions in Kimberlites and Other Volcanics", Boyd, F.R. and Meyer, H.O.A., eds. Am. Geophys. Union Special Publ. Vol 2, 173-182.

Carswell, D.A. (1975): Phys. Chem. Earth 9, 417-430.

Carswell, D.A., D.B. Clarke and R.H. Mitchell (1979): In "The Mantle Sample: Inclusions in Kimberlites and Other Volcanics", Boyd, F.R. and Meyer, H.O.A., eds. Am. Geophys. Union Special Publ. Vol. 2, $127-144$.

Mercier, J.C.C. (1980): Tectonophysics 70, 1-37.

Mitchell, R. H., D.A. Carswell and D.B. Clarke (1980): Contrib. Min. Pet. 72, 205-217.

Wyll1e, P.J. (1980): J. Geophys. Res. 85, 6902-6910.

\title{
NATURE OF THE CONTINENTAL UPPER-MANTLE/LOWER-CRUST TRANSITION BENEATH KILBOURNE HOLE, NEW MEXICO
}

\section{BUSSOD}

Department of Earth and Space Scknccs unversily it Calforma. Los Angeles CA 90024

Models of the continental upper mantle-lower crust transition zone are principally constrained by the study of xenoliths brought to the earth's surface by basaltic magmas. However, because xenoliths occur in restricted tectonic environments closely associated with basaltic volcanism, they do not necessarily represent a typical sample of the 1 ithosphere but a modiffed product formed in response to the thermal evolution of such regions. The information obtained from xenoliths is limited by our ability to reconstruct the mechanical and thermal history of the samples. Xenoliths of both crustal and mantle rocks are abundant at Kilbourne Hole and help to constrain the rheology, composition and thermal regime of the crust-mantle boundary beneath the Rio Grande Rift.

\section{Crustal Xenoliths}

The crustal xenoliths from Kilbourne Hole point to the existence of a granulite facies metamorphic complex composed of garnet and two-pyroxene granulites, garnet orthopyroxenites, anorthosites and charnockites (Padovani and Carter, 1977). Estimated peak temperatures of $1000-1100^{\circ} \mathrm{C}$ intimate that the lower crust was partially melted and recrystallized as fine-grained anhydrous granulites. The transient nature of this thermal event is inferred from local mineral disequilibrium (zoning) of the constituent mineral phases, indicating subsequent slow cooling (Padovani and Hart, 1981).
Mantle Xenoliths

The mantle xenoliths include dunites, harzburgites, both members of the Cr-diopside spinel iherzolite

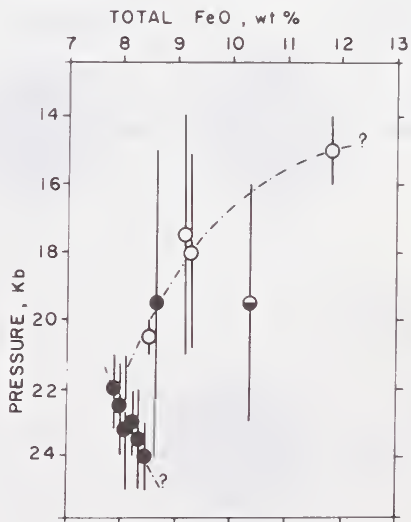

Fig. 1. Bulk FeO vs. average of two independent barometric estimates for granuloblastic (open circles), protogranular (filled circles) and composite xenoliths. 
suite and the Al-Ti augite suite as well as rare composites and megacrysts. The spinel lherzolites are the most abundant and can be subdivided into two textural types: granuloblastic (fine grained) and protogranular (coarse grained). Both are occasionally cut by spinel pyroxenite veins (composites), interpreted as products of flow crystallization (Irving, 1980). No structural relationship has been observed between the two lherzolite types which are also dissimilar in their bulk chemistry: granuloblastic samples show a wider range in the $\mathrm{Mg} / \mathrm{Fe}$ ratios of the constituent phases and generally higher bulk $\mathrm{Fe}$ and LREE than the protogranular samples (Irving, 1980).

Independent pressure estimates from two separate geobarometric calibrations (Finnerty and Boyd, 1978; Dixon and Presnal1, 1980) suggest that the spinel lherzolites were sampled over a large pressure interval $(10 \mathrm{~kb})$ and that the most Fe-rich granuloblastic xenoliths are from shallower depths than the more depleted protogranular xenoliths (Fig. 1). Similar relationships have been described by Mercier (1977) for the adjoining Basin and Range and Colorado Plateau provinces which suggest some lateral continuity. In the composite samples, pyroxenite veins cutting the Fe-rich therzolites are usually at high angles to the foliation when present and are bordered by narrow zones of Fe-poor (depleted) lherzolite. This feature is interpreted as localized partial melting of the host 1herzolite (Bussod, 1981) and implies that the Fe-rich composition of the granuloblastic samples predates the intrusive event.

The two therzolite varieties also differ in the preferred orientations of olivine. The symmetry of olivine fabrics is orthorhombic for both types and is interpreted as resulting from preferential slip on [100] (010), the dominant slip system at high temperatures. However, the olivine fabrics in the protogranular samples are more nearly axial about [010], perhaps the result of a variation in mantle rheology with depth. Olivine fabrics from composite samples are more complex, though their symmetry is also dominantly orthorhombic. Weak girdles about a [010] maximum are typically present and may be due to the formation of pyroxenite or amphibole-bearing veins visible in these samples. This would imply that, unlike the compositional variation, the variety in olivine preferred orientations may be localized to narrow zones affected by the advective transfer of heat from conduit walls.

Olivine-spinel (Fabriés, 1979) and two-pyroxene thermometers (We11s, 1977) were app1.ied to all the 1herzolitic assemblages studied. Temperatures derived from the two methods are in good agreement for the protogranular xenoliths and yjeld apparent equilibration temperatures between $950^{\circ} \mathrm{C}$ and $1050^{\circ} \mathrm{C}$. However, large temperature discrepancies are found using the two methods for the granuloblastic and composite samples (Fig. 2). For these rocks, the spinel is demonstrably out of equilibrium with the silicate phases, but neither this disequilibrium nor the inherent differences between the thermometers can account for such large temperature differences. This is attributed to a recent in situ thermal perturbation (with temperatures up to $1150^{\circ} \mathrm{C}$ ) affecting only the shallower granuloblastic and composite samples. Experimental work on the diffusion rates in spinels (Freer, 1980) and

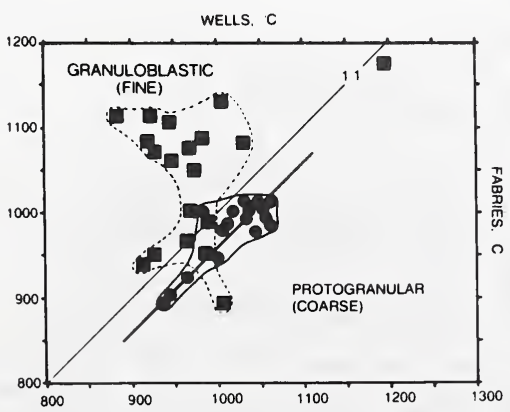

Fig. 2. Evaluation of thermometric estimates for granuloblastic (squares) and protogranular samples (circles).

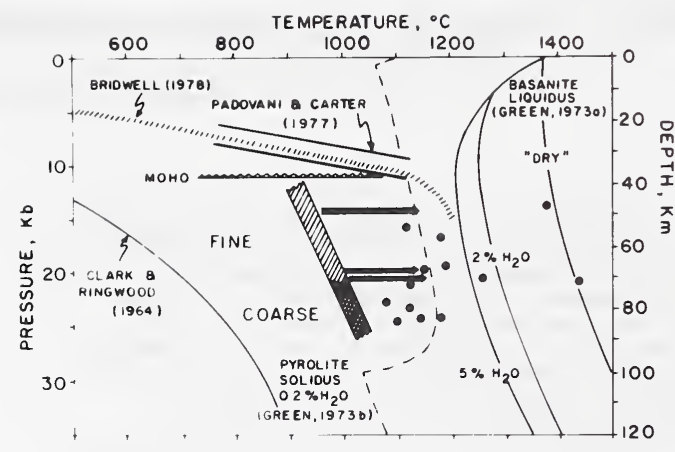

Fig. 3. Mantile and crustal geotherms. Cmistal geotherm from Padovani and Carter (1977) and Bridwell (1978). Mantle geotherm, this study. Arrows indicate estimates of reset olivine-spinel equilibration temperatures in granuloblastic samples. Black dots are thermometric estimates from the Ca content of olivine rims using the experimental calibration of Finnertu and Boyd (1978).

examination of the Ca-zoning profiles of the coexisting silicate phases support this hypothesis.

\section{Discussion}

The P-T relations obtained from the upper mantle and crustal xenoliths from Kilbourne Hole demonstrate that the 1ithosphere has been sampled continuously from a depth of $80 \mathrm{~km}$ (Fig. 3). The mantle thermal gradient of $10^{\circ} \mathrm{C} / \mathrm{km}$ agrees well with similar determinations for this region (Reid, 1976; Mercier, 1977). Yet is is difficult to connect the $30^{\circ} \mathrm{C} / \mathrm{km}$ crustal gradient geotherm to the upper mantle geotherm. Evidence of a recent thermal overprint in the uppermost mantle can be attributed to the development of a basaltic conduit system prior to and during incorporation and transport of the xenoliths to the surface (Bussod and Irving, 1981). Granulite facies metamorphism of the lower crust can be attributed to the conductive heating from a similar conduit system developed in the upper mantle and/or lower crust during the earlier stages of rifting. The granuloblastic texture in the mantle and fine-grained textures in the crustal rocks developed under a deviatoric stress regime during these local thermal episodes. However, the compositional stratification of the upper mantle probably predates rifting and appears laterally extensive, indicating that a $30 \mathrm{~km}$ layer of undepleted dense mantle exists between the lower crust and a depleted residual mantle.

\section{References}

Bussod G. Y., 1981: M.S. Thesis, Univ. of Washington, Seattle.

Bussod G. Y., and A. J. Irving, 1981: in Coriference on the Processes of Planetary Rifting, Lunar and Planetary Institute, Houston.

Bridwel1 R. J., 1978: New Mexico Bur. Mines Mineral Res., Circular 163.

Dixon J. R., and D. C. Presnal1, 1980: Geol. Soc. Amer. Abstr. Progr., 12, 414.

Fabriés J., 1979: Contrib. Mineral. Petrol., 69, 329336 .

Finnerty T. A., and F. R. Boyd, 1978: Carnegie Inst. Wash. Yearbook, 77, 713-717.

Freer R., 1980: Jour. Mat. Sci., 15, 803-824.

Green D. H., 1973a: Earth Planet. Sci. Lett., 17, 456465 .

Green D. H., 1973b: Earth Planet. Sci. Lett., 19, 3753.

Irving A. J., 1980: Amer. J. Sci., 280a, 389-426.

Mercier J. C., 1977: Ph.D. Dissert., State Univ. of New York, Stonybrook.

Padovani E. R., and J. L. Carter, 1977: in The Earth's Crust, ed.: J. G. Heacock, Amer. Geophys. Union, Geophys. Monograph 20, 19-55.

Reid J. B., Jr., 1976: Geo1. Soc. Amer. Abstr. Progr., $\underline{8}, 621$.

Wells P.'R. A., 1977: Contrib. Mineral. Petrol., 62, 129-139. 